\title{
Correlation between satisfaction aspects and the work of speech therapists of a hearing health care network
}

Andrezza Gonzalez Escarce ${ }^{(1)}$

Stela Maris Aguiar Lemos ${ }^{(1)}$

Sirley Alves da Silva Carvalho(1)

(1) Faculdade de Medicina da Universidade Federal de Minas Gerais - UFMG - Belo Horizonte, Minas Gerais, Brazil. Research support source: Fundação de Amparo a Pesquisa do Estado de Minas Gerais (FAPEMIG) - Edital PPSUS/2009.

Conflict of interest: Nonexistent

Received on: April 10, 2017

Accepted on: September 28, 2017

Mailing address:

Andrezza Gonzalez Escarce

Department of Speech Therapy of the

Medical School of the Federal University of Minas Gerais

Av. Professor Alfredo Balena, 190/Sala 249 - Santa Efigênia

CEP: 30.130-100 - Belo Horizonte, Minas

Gerais, Brasil

E-mail: andrezza.ge@gmail.com

\section{ABSTRACT}

Purpose: to correlate aspects involved in the satisfaction of speech therapists with the work in the Hearing Health Care Network regarding human resources policy, provided assistance and communication relationships.

Methods: an analytical observational cross-sectional study, consisting of 27 speech therapists connected to the Hearing Health Care Network. A structured questionnaire was used as the collection instrument. A descriptive analysis of the frequency distribution of all categorical variables and analysis of the measures of central tendency and of dispersion of the continuous variables were made. The Spearman correlation coefficient was used for the correlation analysis.

Results: the analysis revealed a positive correlation with statistical significance of moderate magnitude between the following items: "human resources policy» and «wage policy,» «performance perspective» and «communication»; «activities performed» and «physical space», «wage policy», «performance perspective» and «work routine»; «agenda» and «physical space» and «work routine».

Conclusion: the study showed the influence of the human resources policy, the assistance provided and the communicative relations in the satisfaction with the job of Speech Therapists of a Hearing Health Care Network. In addition, it presented advances in analyzing a poorly addressed network.

Keywords: Speech, Language and Hearing Sciences; Unified Health System; Job Satisfaction; Human Resources; Communication 


\section{INTRODUCTION}

Compared to the insertion of other health professionals, the insertion and actuation of speech therapists in the Unified Health System (SUS) is something relatively recent, but that has shown significant growth ${ }^{1-4}$, mainly favored by the creation of National Health Policies ${ }^{4}$. For that, concepts and practices were reviewed in order to offer quality services, respecting the precepts proposed by SUS ${ }^{3,4}$. Prior to its insertion, the profession of speech therapist was mainly focused on rehabilitation, working at secondary and tertiary care levels ${ }^{4,5}$. Therefore, it is necessary to emphasize the importance of its performance also in the promotion and assistance to health ${ }^{4,5}$, essential for the assistance in basic care.

Parallel to this growth, the Hearing Health Care Networks were created through the Ministerial Decree No. 587 of October $7,2004^{6}$, in order to promote the integral service for the users of Hearing Aid. In this new perspective, the speech therapist plays an essential role, acting at all care levels, from user acceptance to rehabilitation?. Therefore, to know the profile of the speech therapists that work in this Network is essential to foster the awareness of the importance of their actuation not only in rehabilitation practices, but also in actions of health promotion.

In addition, in consideration to the efficiency of the service offered to the population, it is also important to observe the satisfaction of the speech therapist that works in the Network, since a dissatisfied professional affects not only the offered service but also the organization and the work staff-10.

Work is a way for men to position themselves as single individuals, to give meaning and complement life $^{11}$. Thus, satisfaction/happiness with work is taken as a result of the full satisfaction of psychosocial needs and of the feeling of pleasure and contribution exerted through the professional activity ${ }^{11}$.

Studies show that job satisfaction and motivation involve satisfaction with aspects related to human resources policy, remuneration, good communication with the work team, favorable working conditions and possibility of professional recognition and growth ${ }^{9,12}$.

Communication is highlighted not only because it is the subject of speech-language pathology studies, but also because it is an element that integrates workers from different areas within the same institution ${ }^{13}$. So, everybody gains "voice" in the decision making, and communication becomes an important work tool in service management, especially in services of the
Unified Health System (SUS), since the popular and professional participation in decision making can guarantee greater productivity in the service ${ }^{13}$. In addition, failures on communication and teamwork have been pointed out as the main factors that contribute to medical errors, adverse events and worsening of the quality of the offered service ${ }^{14}$.

In view of the above, the purpose of this work was to correlate aspects involved in the satisfaction of speech therapists with the work in the Hearing Health Care Network regarding human resources policy, provided assistance and communication relationships.

\section{METHODS}

\section{Study design}

This is an analytical observational cross-sectional study, consisting of 27 speech therapists linked to the Hearing Health Care Network.

This research was funded by the Foundation for Research Support of Minas Gerais (FAPEMIG) and is part of the project "Evaluation of the implementation of the hearing health care network: a case study of the micro-regions of Sete Lagoas and Curvelo", approved by the Research Ethics Committee of the Federal University of Minas Gerais under the opinion ETIC 186-10.

\section{Scenario of the study}

According to the Regionalization Master Plan (PDR) of 2008, in force at the time of data collection, the 853 municipalities of the state were distributed and organized into 13 health macro-regions, with 19 polo-cities and 75 health micro-regions. The objective of this division is to promote, through regionalization, the structuring of the health services in the state, establishing geographic and population bases for the calculation of the needs for the application of health resources. This way, efforts are made in order to provide comprehensive care to the users in all health care levels, since they will find primary care services in their municipality, secondary care within their microregion and high complexity care in the macro-regional poles ${ }^{15}$.

After collection of the PDR data, two micro-regions were randomly selected, Curvelo and Sete Lagoas, both belonging to the Center macro-region, to compose the study scenario.

It should be emphasized that, currently, the nomenclatures health micro- and macro-regions were 
changed to Health Region and Expanded Health Region, respectively ${ }^{16}$. However, it was decided to keep the nomenclatures used at the time of the collection for analysis and discussion of this article.

\section{Casuistry}

For the present study, a non-probabilistic sample was used, emphasizing that all speech therapists were invited to participate. A total of 34 municipalities were visited, with 37 speech therapists working at the municipal level ${ }^{7}$. Of these, a final sample consisting by 27 professionals was obtained. The professionals who signed the Free and Cleared Term of Consent and had an employment relationship with the Hearing Health Care Network for a period equal to or greater than three months were included. Professionals who had previously answered the questionnaire were excluded because they worked in more than one service/municipality of the Network.

\section{Procedures for data collection}

As a collection instrument, a structured questionnaire was used, elaborated by the researchers, published in a previous study ${ }^{17}$, composed of questions related to the sociodemographic and functional profile of the professionals and their satisfaction with:

a) Physical structure of the service: arranged on a Likert scale of five points, in which the response varied from very dissatisfied to very satisfied.

b) Human resources policy: also arranged on a Likert scale of five points, the professionals should report their satisfaction with the wage policy, human resources and prospects for professional growth.

c) Assistance: as well as the previous ones, also arranged on a Likert scale, the professionals should report their satisfaction with the assisted population, their daily schedule and work routine, and also satisfaction with the developed activities.

d) Communication in the work environment: the professionals should report their satisfaction with the way they communicate in the work environment (from very dissatisfied to very satisfied) and their perception regarding the influence of their communicative relations, i. e., if these impair or assist in the work environment (these items were also arranged on a Likert scale).

The data were collected through individual interviews, with duration of 30 minutes in average, made by speech therapists with fellowship of Technical Support and previously trained, who traveled to the selected municipalities in the period between April 2011 and February 2012. All interviews were digitally recorded.

The recruitment of the participants of the research occurred after consent of the health manager of the municipality. To that end, the manager of each municipality was asked to list all the speech therapists working in the Hearing Health Care Network. All of them were invited to participate and the contact was made via e-mail or telephone, in which guidance about the research was given and the invitation to participate was made. The interviews took place in the own workplace of the professionals, in their exclusive care room, without any interference of other professionals.

\section{Data analysis}

All interviews were transcribed, categorized according to the characteristic of the variable and inserted in a database previously elaborated by the researchers.

A descriptive analysis of the frequency distribution of all categorical variables and analysis of the measures of central tendency and of dispersion of the continuous variables was made. For a better analysis of the items related to the satisfaction of professionals, the variables were transformed and standardized, as described below:

a) Variables that presented their items arranged on a Likert scale of five points, distributed as follows: 1- very dissatisfied, 2- dissatisfied; 3- indifferent; 4satisfied and 5- very satisfied were transformed in a scale that varied between -1 and 1 . Values close to -1 indicated dissatisfaction, close to 0 neutrality and close to 1 satisfaction.

b) Variables with items on a scale of four points: 1slightly harm, 2- indifferent, 3- assist, 4- assist a lot, were also transformed in a scale of points, which values were distributed between -1 and 1. Values close to -1 indicated that they harmed, close to 0 indifference, and close to 1 that they assisted.

For the correlation analysis, the Spearman correlation coefficient was used, which measures the degree of association between the variables. The selection of this test is due to the fact that none of the variables present normal distribution. As a classification of the degree of correlation, that is, of the force between the variables, the following parameter was used ${ }^{18}$ : weak when $0<r<0.4$; moderate when $0.4<r<0.7$ and 
strong when $0.7<r<1.0$. Correlations with statistical significance were considered those with $p \leq 0.05$ and moderate or strong degree of correlation.

The software Statistical Package for the Social Sciences (SPSS), version 21.0 was used for the data entry, processing and analysis.

\section{RESULTS}

The quantitative analysis of the socio-demographic profile of the 27 speech therapists interviewed (Table
1) showed that all of them were female, most of them under 30 years old (55.6\%), postgraduate (59.3\%), had an employment contract $(74.1 \%)$ and received between two and four minimum wages (63.0\%). It should be noted that, at that time, the current minimum wage was $\mathrm{R} \$ 545.00$ and that the salary variation is due to the fact that each municipality has autonomy to define it, since the majority had an employment relationship, not by means of public competition. The average duration of employment was 38.4 months.

Table 1. Sociodemographic profile of speech-language therapists interviewed

\begin{tabular}{|c|c|c|c|}
\hline Variables & Categories of the variable & N-Valid & $\%$ \\
\hline \multirow{3}{*}{ Gender } & Female & 27 & 100.0 \\
\hline & Male & 0 & 0.0 \\
\hline & Total & 27 & 100.0 \\
\hline \multirow{3}{*}{ Age } & Up to 30 years & 15 & 55.6 \\
\hline & Under 30 years old & 12 & 44.4 \\
\hline & Total & 27 & 100.0 \\
\hline \multirow{3}{*}{ Academic education } & Higher education & 11 & 40.7 \\
\hline & Postgraduate & 16 & 59.3 \\
\hline & Total & 27 & 100.0 \\
\hline \multirow{3}{*}{ Employment relationship } & Employment insolvent & 7 & 25.9 \\
\hline & Employment contract & 20 & 74.1 \\
\hline & Total & 27 & 100.0 \\
\hline \multirow{3}{*}{ Salary range } & Up to two minimum wages & 10 & 37.0 \\
\hline & Between two and four minimum wages & 17 & 63.0 \\
\hline & Total & 27 & 100.0 \\
\hline
\end{tabular}

Table 2 shows the distribution of the satisfaction variables, where is possible to observe by the averages found that, in most aspects, the speech therapists were satisfied with the items evaluated, being the activities developed, communication and communicative relations the best evaluated ones. Salary and human resources policy were dissatisfaction items, although with average values close to zero. 
Table 2. Distribution of satisfaction variables

\begin{tabular}{cccccccc}
\hline Variables & Media & S.D. & Minimum & 1st Quartile & Median & 2nd Quartile & Maximum \\
\hline Physical space & 0.13 & 0.66 & -1.00 & -0.50 & 0.50 & 0.50 & 1.00 \\
Wage policy & -0.26 & 0.61 & -1.00 & -0.50 & -0.50 & 0.50 & 1.00 \\
Human Res. policy & -0.15 & 0.63 & -1.00 & -0.63 & -0.25 & 0.50 & 0.50 \\
Prosp. performance & 0.33 & 0.59 & -1.00 & 0.50 & 0.50 & 0.50 & 1.00 \\
Served population & 0.50 & 0.42 & -0.50 & 0.50 & 0.50 & 0.50 & 1.00 \\
Agenda & 0.30 & 0.51 & -0.50 & -0.50 & 0.50 & 0.50 & 1.00 \\
Work routine & 0.41 & 0.44 & -0.50 & -0.50 & 0.50 & 0.50 & 1.00 \\
Developed activities & 0.48 & 0.41 & -0.50 & 0.50 & 0.50 & 0.50 & 1.00 \\
Communicative & 0.48 & 0.35 & -0.50 & 0.50 & 0.50 & 0.50 & 1.00 \\
Commun. relations & 0.61 & 0.45 & -1.00 & 0.50 & 0.50 & 1.00 & 1.00 \\
\hline
\end{tabular}

Legend: S.D. = standard deviation; Res. $=$ Resources; Prosp. $=$ Prospect; Commun. $=$ Communicative

In the Spearman's correlation analysis between the variables related to satisfaction, a positive correlation with statistical significance of moderate magnitude was observed between the following items: "human resources policy" and "wage policy" (0.50), "prospects for professional growth" (0.54) and "communication" (0.44); "developed activities" and "physical space"
(0.41), "wage policy" (0.40), "prospects for professional growth" (0.44) and "work routine" (0.49); "schedule" and "physical space" (0.43) and "work routine" (0.63). Such positive correlations indicate that: if an item was evaluated as satisfactory, the other also tended to be satisfactory, at a significance level of $5 \%$ (Table 3 ).

Table 3. Correlation analysis between satisfaction variables

\begin{tabular}{cccccccccc}
\hline $\begin{array}{c}\text { Satisfaction } \\
\text { Variables }\end{array}$ & $\begin{array}{c}\text { Physical } \\
\text { space }\end{array}$ & $\begin{array}{c}\text { Wage } \\
\text { policy }\end{array}$ & $\begin{array}{c}\text { H. Res. } \\
\text { policy }\end{array}$ & $\begin{array}{c}\text { Prosp. } \\
\text { Perf. }\end{array}$ & $\begin{array}{c}\text { Served } \\
\text { pop. }\end{array}$ & Agenda & $\begin{array}{c}\text { Work } \\
\text { routine }\end{array}$ & $\begin{array}{c}\text { Developed } \\
\text { act. }\end{array}$ & $\begin{array}{c}\text { Com. } \\
\text { Com. } \\
\text { relations }\end{array}$ \\
\hline Physical space & 1.00 & & & & & & & & \\
Wage policy & 0.37 & 1.00 & & & & & & & \\
Human Res. policy & 0.28 & $\mathbf{0 . 5 0}$ & 1.00 & & & & & & \\
Prosp. Perf. & 0.32 & 0.28 & $\mathbf{0 . 5 4}$ & 1.00 & & & & \\
Served population & 0.03 & 0.22 & 0.09 & 0.21 & 1.00 & & & \\
Agenda & $\mathbf{0 . 4 3}$ & 0.17 & 0.33 & 0.30 & 0.03 & 1.00 & & \\
Work routine & 0.29 & 0.20 & 0.17 & 0.21 & 0.23 & $\mathbf{0 . 6 3}$ & 1.00 & \\
Developed act. & $\mathbf{0 . 4 1}$ & $\mathbf{0 . 4 0}$ & 0.32 & $\mathbf{0 . 4 4}$ & 0.07 & 0.38 & $\mathbf{0 . 4 9}$ & 1.00 & \\
Communicative & 0.10 & 0.12 & $\mathbf{0 . 4 4}$ & 0.24 & -0.26 & 0.12 & -0.01 & 0.13 & 1.00 \\
Com. relations & 0.20 & -0.05 & 0.30 & -0.06 & -0.25 & 0.32 & 0.15 & 0.30 & 0.37 \\
\hline
\end{tabular}

Spearman Correlation

Legend: bold $=p \leq 0,05 ;$ H. Res $=$ Human Resources; Prosp. perf.. = Prospective performance; Pop.$=$ Population; Act. $=$ activities; Com. $=$ Communicative

\section{DISCUSSION}

The characterization of the sample showed that all individuals of it were female, most of them under 30 years old, postgraduate, had an employment contract and received between two and four minimum wages. The predominance of the female gender points to an inherent characteristic of the profession, also highlighted in another study ${ }^{19}$. The other characteristics were also pointed out in previous studies ${ }^{19-21}$, showing that the majority was also aged up to 30 years, postgraduate, and worked as autonomous or had an employment contract. The only characteristic that indicates differences in the present study concerns the salary range, which is lower than that found in previous studies $^{20,21}$. The purpose of these studies ${ }^{20,21}$ was to describe the profile of speech therapists working in two specific municipalities, one with speech therapists from 
all areas $^{20}$ and the other with speech therapists working in the area of clinical audiology ${ }^{21}$. The studies revealed that the remuneration of the speech therapists was up to five minimum wages ${ }^{20}$ and between four and six minimum wages ${ }^{21}$, respectively.

The correlation analysis revealed that speech therapists who were satisfied with the human resources policy tended to be satisfied with the prospects for professional growth, communication and wage policy. The literature 22 points out that to be satisfied at work involves being in an adequate work system and with fair treatment. In order to achieve these aspects it is essential that the professionals feel that their work is recognized through a good perspective of growth and remuneration ${ }^{23,24}$, but also through a good relationship and communication with co-workers ${ }^{22-25}$. These findings corroborate data from the literature ${ }^{22}$ regarding the concept that to be satisfied with employment and human resources policy involves several factors and not only remuneration, although this is often indicated as the main cause of dissatisfaction.

In addition, a study carried out with nurses working in the hospital environment revealed that to be accepted in the group is extremely relevant for the professional, since a good relationship with co-workers implies less work stress ${ }^{26}$ and, therefore, greater satisfaction.

Also with respect to communication, it is emphasized that such aspect goes beyond the simple fact of being satisfied with the way in which the team communicates. It implies the establishment of a communicative process at all levels of power within the organization, seeking the recognition of all involved in the work process, solving problems together and involving everyone, from the manager to the final element, that is, the user ${ }^{13}$. The importance of this result is emphasized, since communication is one of the action areas of speech therapists.

The correlation analysis also revealed that to be satisfied with the developed activities tended to indicate greater satisfaction with the physical space, salary policy, prospects for professional growth and work routine. In order to be satisfied with the job, first of all it is necessary to enjoy what you do ${ }^{25}$. In addition, satisfaction with the routine, space and conditions offered for the accomplishment of the work, as well as a good remuneration and the possibility of recognition through professional growth within the institution.

Also in relation to the remuneration aspect, although it is a recurrent factor in discussions about job satisfaction, in most cases, alone this is not a reason for dissatisfaction ${ }^{21}$. However, its importance is highlighted for the feeling of appreciation and recognition by the professional. Thus, the importance of having such aspect related to satisfaction with the activities developed is justified. It indicates that the professionals like what they do, feel valued and well paid. In addition, it should be noted that the majority of the sample is post-graduate, which, according to the literature ${ }^{27}$, represents greater decision-making power in relation to the work and, consequently, in relation to the aspects discussed. In addition, remuneration directly affects the professional's sense of achievement, but depends on the demands and expectations of each individual ${ }^{25}$.

The prospects for professional growth, mentioned in both correlations analyzed, involve the expectation of the professionals to obtain respect and recognition for their work, characterized by the institutional growth. To be satisfied with the prospects for professional growth allows us to infer that the professionals do not consider their work restricted or monotonous. These are factors that lead to discouragement and lack of interest in the execution of the tasks ${ }^{26}$ and to job dissatisfaction.

The positive correlation of moderate magnitude found between schedule, work routine and physical space is also highlighted. Regarding schedule and work routine, it is believed that these aspects are interlinked, since the schedule is part of the work routine of the professionals. Thus, it is assumed that satisfaction with the schedule also indicates satisfaction with the work routine. On the other side, physical space is referenced $^{11}$ as a determinant factor for the performance of the professionals and, consequently, of their satisfaction, since an inadequate physical space is directly related to working conditions.

The study of the satisfaction of the professional is relevant, since the literature indicates that to be satisfied not only motivates the professional for improvement, but also improves the quality of care provided to the population ${ }^{28}$.

This study presents as limitations the reduced sample and the fact that it is a Hearing Health Care Network of a specific region, making it difficult to perform generalizations and comparisons. However, it presents advances regarding the delineation of the profile and satisfaction of speech therapists with the Hearing Health Care Network, in addition to the realization of interviews in the own municipality of the professional. The need for more studies addressing these aspects is highlighted, since the Network and the performance of speech therapists in the Unified Health 
System (SUS) are relatively recent, making it necessary to be known by the scientific community.

\section{CONCLUSION}

This study analyzed the correlation between aspects involved in the satisfaction of speech therapists with the work in the Hearing Health Care Network and revealed a positive statistically significant correlation between items related to human resources policy, assistance and communication. It was also verified that speech therapists of the Hearing Health Care Network were satisfied with most of the items analyzed, being developed activities, communication and communicative relations the best evaluated ones. On the other hand, salary and human resources appear as the main items of dissatisfaction.

The studied aspects allowed to verify a positive correlation of moderate magnitude with factors of satisfaction of speech therapists, among which human resources policy, developed activities and schedule are mentioned.

The present study also presented advances related to the delineation of the profile and satisfaction of speech therapists of the Hearing Health Care Network, mainly due to the fact that it is a Network that has not been approached in studies.

\section{REFERENCES}

1. Molhi-Avejonas DR, Aboboreira MS, Couto MIV, Samelli AG. Insertion and performance of speechlanguage pathology and audiology in Family Health Suport Centers. CoDAS. 2014;26(2):148-54.

2. Lipay MS, Almeida EC. A fonoaudiologia e sua inserção na saúde pública. Rev Ciênc Méd. 2007;16(1):31-41.

3. Moreira MD, Mota HB. The ways of the speechlanguage therapy in the Unique System of Health - SUS. Rev. CEFAC. 2009;11(3):516-21.

4. Santos JN, Maciel FJ, Martins VO, Rodrigues ALV, Gonzaga AF, Silva LF. Insertion of speech therapists in SUS/MG and their distribution in Minas Gerais state. Rev. CEFAC. 2012;14(2):196-205.

5. Silva MEML, Brasil CCP, Regis ACF. Desafio do núcleo de atenção médica integrada diante da necessidade de inserção de fonoaudiólogo na Rede Municipal de Saúde de Fortaleza. Saúde Soc. 2010;19(4):838-51 .

6. Ministério da Saúde (BR). Secretaria de Atenção à Saúde. Portaria № 587, de 7 de outubro de 2004.
[Dispõe sobre a organização e a implantação das Redes Estaduais de Atenção à Saúde Auditiva]. Diário Oficial União. 11 out. 2004.

7. Minas Gerais. Secretaria de Estado de Saúde. Resolução SES № 1669, de 19 de novembro de 2008 [citado 10 nov 2014]. Aprova o fluxo de inclusão na Rede Estadual de Saúde Auditiva de Minas Gerais e define atribuições do Fonoaudiólogo Descentralizado, da Junta de Saúde Auditiva Microrregional e da Junta Reguladora da Saúde Auditiva. Disponível em: http://ws.mpmg.mp.br/ biblio/informa/281111128.htm.

8. Locke EA. What is job satisfaction? Org Behav Human Perf. 1969;4(4):309-36.

9. Rebouças D, Legay LF, Abelha L. Satisfação com o trabalho e impacto causado nos profissionais de serviço de saúde mental. Rev Saúde Púb. 2007;41(2):244-50.

10. Thofehrn MB, Montesinos MJL, Jacondino MB, Fernandes HN, Gallo CMC, Figueira AB. Work processes of nurses in health production in a University Hospital in Murcia/Spain. Ciênc Cuid Saúde. 2015;14(1):924-32.

11. Martinez MC, Paraguay AIBB. Satisfação e saúde no trabalho - aspectos conceituais e metodológicos. Cad Psicol Social Trab. 2003;6:59-78.

12. Cavanagh SJ. Job satisfaction of nursing staff working in hospitals. J Adv Nurs. 1992;17(6):704-11.

13. Ferreira MC, Maciel FJ, Castro LA, Lemos SMA. Study of communicative relations in the management process of a health institution. Rev. CEFAC. 2013;15(6):1560-9.

14. Nogueira JWS, Rodrigues MCS. Effective communication in teamwork in health: a challenge for patient safety. Cogitare Enferm. 2015;20(3):636-40.

15. Minas Gerais. Secretaria de Estado de Saúde. Deliberação CIB-SUS/MG no 483, de 22 de outubro de 2008 [citado 10 nov 2014]. Aprova o ajuste do Plano Diretor de Regionalização - PDR/ MG. Disponível em: http://www.saude.mg.gov. br/images/documentos/Anexo\%20III\%20da\%20 Del\%20483\%20Ajuste\%20PDR\%202008.pdf.

16. Minas Gerais. Secretaria de Estado de Saúde. Deliberação CIB-SUS/MG $n^{\circ}$ 1.219, de 21 de agosto de 2012 [citado em 10 nov 2014]. Institui as Regiões de Saúde no âmbito do Sistema Único de Saúde (SUS) para o estado de Minas Gerais, e dá outras providências. Disponível em: http:// www.saude.mg.gov.br/images/documentos/ 
Deliberacao\%201.219\%20-\%20Regioes\%20de\%20 Saude\%20-\%2021.8.12.pdf.

17. Escarce AG, Lemos SMA, Carvalho SAS. Profile and work satisfaction among professionals of hearing care health network. ACR. 2015;20(2):96-103.

18. Siqueira AL, Tibúrcio JD. Estatística na área da saúde: conceitos, metodologia, aplicações e prática computacional. Belo Horizonte (MG). Coopmed. 2011.

19. Teixeira LC, Rodrigues ALV, Santos JN, Cardoso AFR, Gama ACC, Resende LM. Professional trajectory of graduates in Speech, Language and Hearing Sciences. Rev. CEFAC. 2013;15(6):1591-600.

20. Stefaneli FR, Monteiro KDGM, Spinelli RL. Perfil do fonoaudiólogo na cidade de São José dos Campos. Rev. CEFAC. 2004;6(1):101-5.

21. Braga CM, Martins KVC, Queiroz MAS, Câmara MFS. Market profile of the phonoaudiologist in the area of clinical audiology. Rev. CEFAC. 2013;15(6):546-51.

22. Souto CMR, Oliveira LMB. Análise da satisfação dos funcionários com as políticas e práticas de recursos humanos utilizadas pelas agências de viagem e turismo da cidade de Recife-PE, Brasil. Turism anál. 2007;18(1):109-24.

23. Matsuda LM, Évora YDM. Ações desenvolvidas para a satisfação no trabalho da equipe de enfermagem de uma UTI-Adulto. Cienc, Cuid e Saúde. 2006;5(Supl):49-56.

24. Danet A, March JC, Romeral G. Communication, participation and leadership in the perception of the emocional climate in a university hospital in Andalusia, Spain. Cad Saude Publica. 2014;30(3):546-58.

25. Batista AAV, Vieira MJ, Cardoso NCS, Carvalho GRP. Fatores de motivação e insatisfação no trabalho do enfermeiro. Rev Esc Enferm USP. 2005;39(1):85-91.

26. Montanholi LL, Tavares DMS, Oliveira GR. Estresse: fatores de risco no trabalho do enfermeiro hospitalar. Rev Bras Enferm. 2006;59(5):661-5.

27. Perterson M, Dunnagan T. Analysis of a worksite health promotion program's impact on job satisfaction. $\mathrm{J}$ Occup Environ Med. 1998;40(11):973-9.

28. Serrano MXM. Satisfação do profissional de saúde da equipe multidisciplinar envolvidos no método mãe canguru [dissertação]. Recife (PE): Programa de Pós-Graduação em Saúde da Criança e do Adolescente da Universidade Federal de Pernambuco; 2012. 